Article

\title{
Molecular Recognition Studies on Naphthyridine Derivatives
}

\section{José Carlos Iglesias-Sánchez ${ }^{1}$, Dolores Santa María ${ }^{1, *}$, Rosa M. Claramunt ${ }^{1}$ and José Elguero ${ }^{2}$}

1 Departamento de Química Orgánica y Bio-Orgánica, Facultad de Ciencias, UNED, Senda del Rey 9, E-28040 Madrid, Spain; E-Mails: jcisanchez@gmail.com (J.C.I-S.); rclaramunt@ccia.uned.es (R.M.C.)

2 Instituto de Química Médica, CSIC, Juan de la Cierva 3, E-28006, Madrid, Spain; E-Mail: iqmbe17@iqm.csic.es (J.E.)

* Author to whom correspondence should be addressed; E-Mail: dsanta@ccia.uned.es; Tel.: + 34913987336; Fax: + 34913988372 .

Received: 14 January 2010; in revised form: 8 February 2010 / Accepted: 1 March 2010 / Published: 3 March 2010

\begin{abstract}
The association constants $K_{b}$ of three hosts I-III designed to have both enhanced hydrogen bonding donor strength and conformational preorganization with biotin analogues 1-5 are reported. ${ }^{1} \mathrm{H}-\mathrm{NMR}$ titrations under two different concentration conditions have been employed to determine the association constants $K_{b}$. A statistical analysis using a presence absence matrix has been applied to calculate the different contributions. Hydrogen bond interactions make naphthyridine derivatives II and III potent binders and effective receptors for $(+)$-biotin methyl ester (1), due to the complex stabilization by additional hydrogen bonds.
\end{abstract}

Keywords: host-guest; naphthyridine; biotin; acridine; NMR titrations

\section{Introduction}

Amide N-H groups have been used to produce a wide range of receptors capable of coordinating biologically important molecules and anions [1,2]. General reviews covering anion receptors containing amide groups have been published recently [3,4]. Due to their singular stereoelectronic character, they interact with electron deficient centers through the carbonyl group and with electron rich centers through their $\mathrm{N}-\mathrm{H}$ units; this dual feature has been successfully used for the design of amide-based receptors able to recognize a large variety of guests [1]. On the other hand the recognition 
capabilities of fused-pyridine and naphthyridine hosts remains an important challenge of supramolecular chemistry [5].

Our previous works have been focused on the design, synthesis and host-guest behaviour of different receptors using biotin methyl ester (1) as model substrate [6-11]. Here we turned our attention to modifications of the latter molecule by comparatively studying a series of $4 S$-substituted (3aR,6aS)-tetrahydro-1H-thieno[3,4-d]imidazol-2(3H)-ones $\mathbf{2}-\mathbf{5}$.

\section{Results and Discussion}

In this paper we report the measurement and analysis of the binding constants, $K_{b}$ of five guests $\mathbf{1}-\mathbf{5}$ with three receptors, namely 3,4,5,6-tetrahydro-3,3,6,6-tetramethylenebis(pyrido[3,2-g]indolo)[2,3$a: 3^{\prime}, 2^{\prime}$-j] acridine (I) [12], N,N'-bis(7-methyl-1,8-naphthyridin-2-yl)-1,3-benzenedicarboxamide (II) [13], and $N, N^{\prime}, N^{\prime}$ '-tris(7-methyl-1,8-naphthyridin-2-yl)-1,3.5-benzenetricarboxamide (III) [8] (Figure 1).

Figure 1. Receptors I-III.

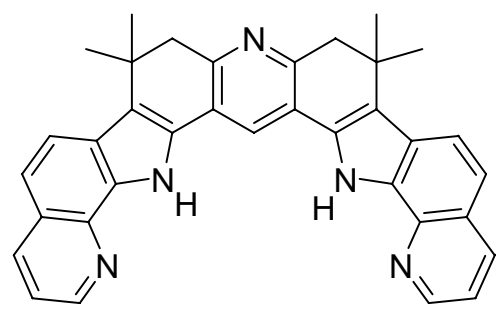

I<smiles>Cc1ccc2ccc(NC(=O)c3cccc(C(=O)Nc4ccc5ccc(C)nc5n4)c3)nc2n1</smiles>

II<smiles>Cc1ccc2ccc(NC(=O)c3cc(C(=O)Nc4ccc5ccc(C)nc5n4)cc(C(=O)Nc4ccc5ccc(C)nc5n4)c3)nc2n1</smiles>

III

Guests 1 [14] and 2-5 [15] were synthesized according to described procedures with slight variations (Figure 2). The first step was the preparation of biotin methyl ester $\mathbf{1}$ by acid-catalyzed esterification of biotin. Selective reduction of 1 using DIBAL at $-78{ }^{\circ} \mathrm{C}$ afforded alcohol 2 in $73 \%$ yield. The iodide 3 was prepared from biotin tosylate by halide substitution with $\mathrm{NaI}$ in acetone. The reaction of 3 with $\mathrm{LiBr}$ in 2-butanone yielded the formation of bromide 4 in $87 \%$ yield. Finally, alkyne 5 was obtained in high yield by the substitution reaction of bromide 4 with lithium acetylideethylenediamine in DMSO at $15^{\circ} \mathrm{C}$.

The ability of receptors containing pyridine or naphthyridine moieties I-III to recognize and bind the aforementioned guests can be evaluated using ${ }^{1} \mathrm{H}-\mathrm{NMR}$ spectroscopy. The stoichiometry of the complexes must be determined beforehand to ensure use of the right equations in the titrations. 
Figure 2. The $4 S$-substituted (3aR,6aS)-tetrahydro- $1 H$-thieno[3,4- $d]$ imidazol-2(3H)-ones 1-5.
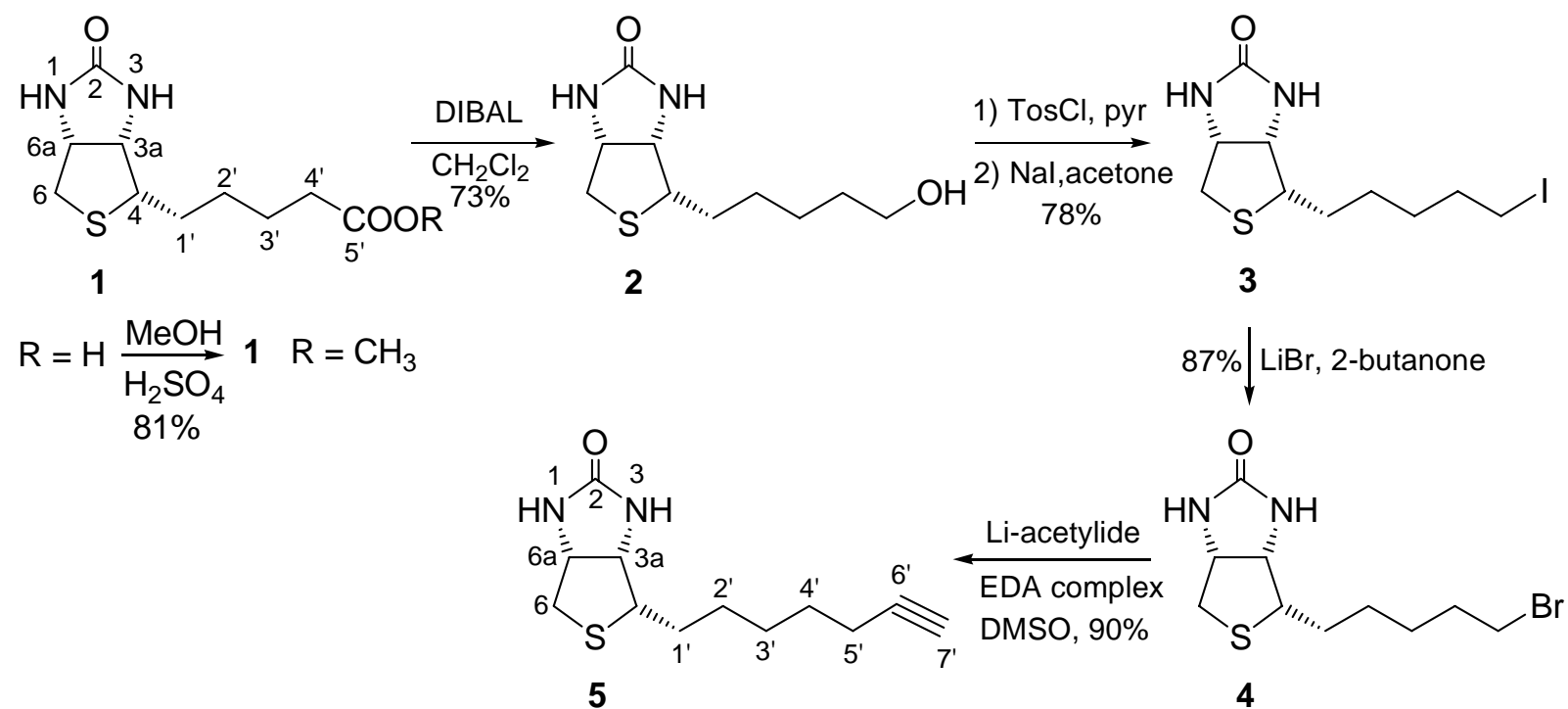

We have used the method of continuous variation to generate Job plots [16] by preparing different mixtures of receptor and guest covering the whole range of molar fractions of the host but keeping constant the total concentration of the solutions $(10 \mathrm{mM})$. The plot of the product between the increment in the chemical shift and the receptor concentration versus the molar fraction of the receptor affords a curve. From the value of the maximum, which can be obtained by means of equation $X=m /(m+n)$ [17], the stoichiometry of the complex is determined. For all the compounds used in this study we always obtained a 1:1 stoichiometry (see Figure 3 for an example).

Figure 3. Job plot corresponding to the complexation of host III with (+)-biotin methyl ester $1([\mathbf{I I I}]+[\mathbf{1}]=10 \mathrm{mM})$.

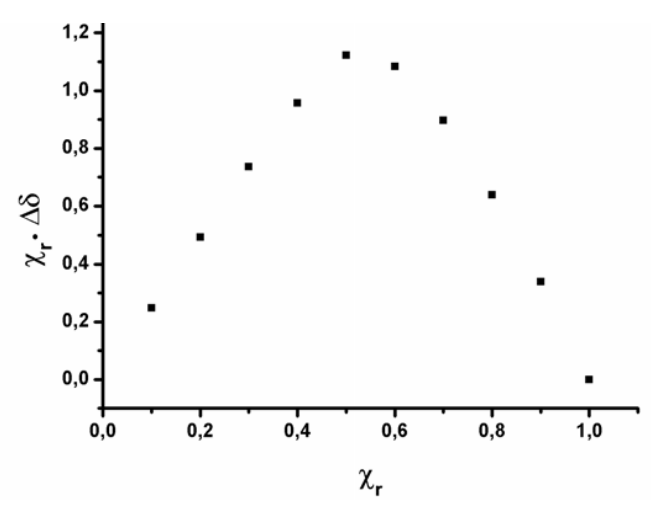

NMR titrations [18] were perfomed at two different experimental concentrations [6]: the non saturation titration conditions $(n S T)$ in the 0.2-08 range and the saturation titration conditions (ST).

\subsection{Binding Studies}

Association constants $K_{b}$ for hosts I-III with biotin derivatives $\mathbf{1}-\mathbf{5}$ as guests were determined by ${ }^{1} \mathrm{H}-\mathrm{NMR}$ titration experiments in $\mathrm{CDCl}_{3}$ using the EQNMR software to fit the curves to a $1: 1$ binding 
model [19]. The values depicted in Table 1 have been calculated from the chemical shift induced effects of the N-H groups of receptors I-III.

Table 1. Association constants $K_{b}\left(\mathrm{M}^{-1}\right)$ for I-III binding $\mathbf{1}-\mathbf{5}$ measured at $300 \mathrm{~K}$ in $\mathrm{CDCl}_{3}$ (Errors $\leq 10 \%$ ).

\begin{tabular}{|c|c|c|c|c|c|c|}
\hline & \multicolumn{2}{|c|}{ I } & \multicolumn{2}{|c|}{ II } & \multicolumn{2}{|c|}{ III } \\
\hline & $K_{\mathbf{b}}^{[\mathrm{a}]}$ & $K_{b}^{[b]}$ & $K_{b}^{[a]}$ & $K_{b}^{[b]}$ & $K_{b}^{[a]}$ & $K_{\mathbf{b}}^{\left[{ }^{[b]}\right.}$ \\
\hline \multirow[t]{2}{*}{1} & 2,700 & 4,200 & 67,000 & 27,200 & 250,000 & 148,000 \\
\hline & & & & & & $100^{[\mathrm{c}]}$ \\
\hline \multirow[t]{2}{*}{2} & [d] & [d] & [d] & [d] & [d] & [d] \\
\hline & & & & & & $110^{[\mathrm{cc}]}$ \\
\hline 3 & 1,500 & 600 & 5,600 & 1,500 & 800 & 150 \\
\hline 4 & 2,000 & 630 & 6,020 & 1,900 & 1,700 & 540 \\
\hline 5 & 1,900 & 244 & 4,700 & 1,000 & 1,000 & 180 \\
\hline
\end{tabular}

${ }^{[a]}$ Saturation Titration conditions $(S T) ;{ }^{[\mathrm{b}]}$ non Saturation Titration conditions $(n S T) ;{ }^{[\mathrm{c}]}$ with $10 \%$ of $\mathrm{MeOD} ;{ }^{[\mathrm{d}]}$ not detected.

We have already reported three $K_{b}$ values of Table 1 using the non Saturation Titration conditions (nST): I·1 3,800 \pm 500 [6], II·1 35,000 \pm 5,250 [6], and III·1 148,000 $\pm 20,000$ [8]. The new values are slightly lower than those determined previously - $(0.99 \pm 0.04)$-fold on average. Addition of biotin analogues $\mathbf{1}-\mathbf{5}$ to $\mathbf{I}-\mathbf{I I I}$ in $\mathrm{CDCl}_{3}$, results in downfield shifts of the $\mathrm{N}-\mathrm{H}$ groups of receptors $\mathbf{I}-\mathbf{I I I}$ due to host-guest hydrogen bonds interactions. The selectivity displayed by all three receptors I-III is similar to the trend $\mathrm{CO}_{2} \mathrm{Me}>>\mathrm{Br} \geq \mathrm{I} \geq$ acetylide (Figure 4).

Figure 4. Variations on the chemical shifts of the N-H group in host III as function of the equivalents of added guest in $S T$ conditions.

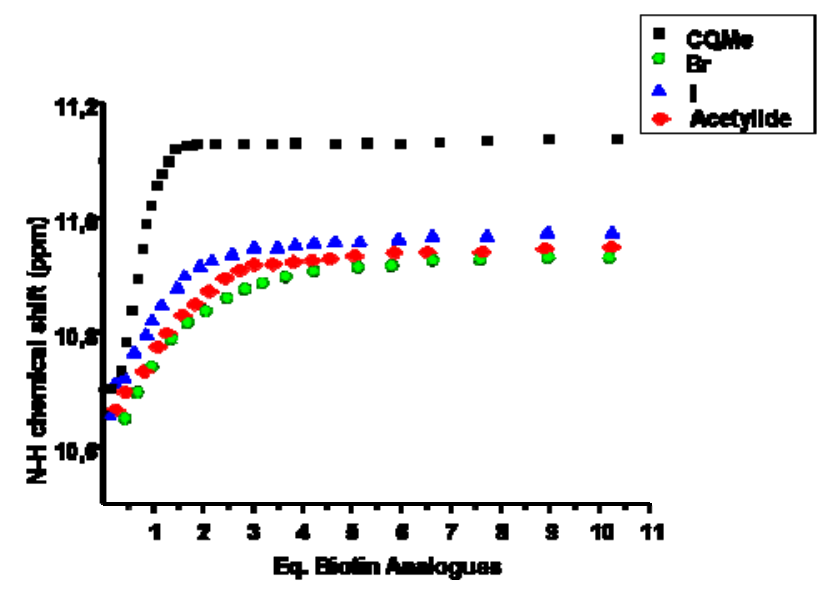

The receptors II and III have high association constants $\left(6.7 \times 10^{4}\right.$ and $2.5 \times 10^{5} \mathrm{M}^{-1}$, respectively) with (+)-biotin methyl ester (1), presumably due to the formation of additional hydrogen bonds with the receptors involving the methyl ester that could further stabilize the complex. In addition, the biotin analogues with bulky groups (Br, I and acetylide) will destabilize the complex due to steric repulsion 
and that seems to be the most important factor influencing the relative poor association constants obtained for these guests.

The biotin analogue 2 was insoluble in $\mathrm{CDCl}_{3}$, therefore in order to compare its behavior with that of the other guests, the ${ }^{1} \mathrm{H}-\mathrm{NMR}$ titration was performed in a $10 \% \mathrm{MeOD}-90 \% \mathrm{CDCl}_{3}$ solution. As control the (+)-biotin methyl ester (1) was titrated under the same conditions as receptor III. The obtained association constants $K_{b}$ were: $100 \mathrm{M}^{-1}$ for $\mathbf{1}$ and $110 \mathrm{M}^{-1}$ for $\mathbf{2}$, suggesting that the latter guest interacts with receptor III in a similar manner as it does $\mathbf{1}$. On the contrary, guest $\mathbf{2}$ does not interact with receptors I and II.

\subsection{Data analysis}

Finally a more quantitative approach on the association constant values has been attempted. First, we have multiplied by 1.1 (from 100 to 110) all the $K_{b}$ values of Table 1 for guest 1 (G1) to estimate the $K_{b}$ values of G2. Since we have two estimations for $K_{b}$ we have calculated the regression line between the $S T$ and $n S T$ methods: $S T=(3,357 \pm 2,388)+(1.68 \pm 0.04) n S T, \mathrm{n}=15, \mathrm{R}^{2}=0.992$, and used the fitted $S T$ values as dependent variables (Table 2). This procedure corresponds to a weighted mixture of both values.

Table 2. Absence-presence matrix.

\begin{tabular}{|c|c|c|c|c|c|c|c|c|c|}
\hline $\begin{array}{l}\text { Compoun } \\
\text { d }\end{array}$ & $K_{b}$ & HI & HII & HIII & G1 & G2 & G3 & G4 & $\ln K_{b}$ \\
\hline $\mathbf{I} \cdot \mathbf{1}$ & 10,447 & 1 & 0 & 0 & 1 & 0 & 0 & 0 & 9.25 \\
\hline II $\cdot 1$ & 49,277 & 0 & 1 & 0 & 1 & 0 & 0 & 0 & 10.80 \\
\hline III'1 & 253,219 & 0 & 0 & 1 & 1 & 0 & 0 & 0 & 12.44 \\
\hline$I \cdot 2$ & 11,156 & 1 & 0 & 0 & 0 & 1 & 0 & 0 & 9.32 \\
\hline II·2 & 53,869 & 0 & 1 & 0 & 0 & 1 & 0 & 0 & 10.89 \\
\hline III.2 & 278,206 & 0 & 0 & 1 & 0 & 1 & 0 & 0 & 12.54 \\
\hline I·3 & 4,370 & 1 & 0 & 0 & 0 & 0 & 1 & 0 & 8.38 \\
\hline II·3 & 4,707 & 0 & 1 & 0 & 0 & 0 & 1 & 0 & 8.46 \\
\hline III·3 & 3,610 & 0 & 0 & 1 & 0 & 0 & 1 & 0 & 8.19 \\
\hline I.4 & 4,420 & 1 & 0 & 0 & 0 & 0 & 0 & 1 & 8.39 \\
\hline II $\cdot 4$ & 6,564 & 0 & 1 & 0 & 0 & 0 & 0 & 1 & 8.79 \\
\hline III 4 & 4,268 & 0 & 0 & 1 & 0 & 0 & 0 & 1 & 8.36 \\
\hline I.5 & 3,769 & 1 & 0 & 0 & 0 & 0 & 0 & 0 & 8.23 \\
\hline II·5 & 5,045 & 0 & 1 & 0 & 0 & 0 & 0 & 0 & 8.53 \\
\hline III.5 & 3,661 & 0 & 0 & 1 & 0 & 0 & 0 & 0 & 8.20 \\
\hline
\end{tabular}

Then we have built a presence/absence matrix (Table 2), known in medicinal chemistry as a FreeWilson model [20,21]. If we assume that $K_{b}=\mathrm{H} \times \mathrm{G}$, then, $\ln K_{b}=\ln \mathrm{H}+\ln \mathrm{G}$. From Table 2 the following contributions can be calculated: $\ln \mathrm{HI}=7.7$, $\ln \mathrm{HII}=8.5, \ln \mathrm{HIII}=9.0, \ln \mathrm{G} 1=2.4$ and $\ln \mathrm{G} 2=2.5$ (the other $\mathrm{G}$ terms are not significant, $\ln =0$ ). These values correspond to $\mathrm{HI}=2,253$, $\mathrm{HII}=4,915$, $\mathrm{HIII}=7,708, \mathrm{G} 1=11.5$ and $\mathrm{G} 2=12.4($ other $\mathrm{G}$ terms $=1)$. 


\section{Experimental}

\subsection{General}

Unless otherwise reported, all reactions were carried out under dry and deoxygenated argon atmospheres. Solvents were freshly distilled and dried before use by standard methods. ${ }^{1} \mathrm{H}$ - and ${ }^{13} \mathrm{C}$ NMR spectra were recorded on a Bruker DRX 400 spectrometer (9.4 Tesla, operating at $400.13 \mathrm{MHz}$ for ${ }^{1} \mathrm{H}$ and $100.62 \mathrm{MHz}$ for ${ }^{13} \mathrm{C}$, respectively) with a $5-\mathrm{mm}$ inverse detection $\mathrm{H}-\mathrm{X}$ probe equipped with a z-gradient coil, at $300 \mathrm{~K}$. Chemical shifts $\left(\delta\right.$, in ppm) are given from internal solvent $\mathrm{CDCl}_{3}(7.26$ for ${ }^{1} \mathrm{H}$ and 77.0 for $\left.{ }^{13} \mathrm{C}\right)$ and DMSO- $d_{6}\left(2.49\right.$ for ${ }^{1} \mathrm{H}$ and 39.5 for $\left.{ }^{13} \mathrm{C}\right)$. 2D gs-COSY $\left({ }^{1} \mathrm{H}-{ }^{1} \mathrm{H}\right)$ and $2 \mathrm{D}$ inverse proton detected heteronuclear shift correlation spectra [gs-HMQC $\left({ }^{1} \mathrm{H}_{-}{ }^{13} \mathrm{C}\right)$ and gs-HMBC $\left({ }^{1} \mathrm{H}-\right.$ $\left.{ }^{13} \mathrm{C}\right)$ ] were acquired and processed using standard Bruker NMR software and in non-phase-sensitive mode and were carried out to assign the ${ }^{1} \mathrm{H}$ and ${ }^{13} \mathrm{C}$ signals without ambiguity.

\subsection{Synthesis}

Methyl 5-[(3aS,4S,6aR)-2-oxo-hexahydro-1H-thieno[3,4-d]imidazol-4-yl]pentanoate (1) [14]. A suspension of D-(+)-biotin $(1 \mathrm{~g}, 4.1 \mathrm{mmol})$ and $\mathrm{H}_{2} \mathrm{SO}_{4}(3 \mathrm{~mL})$ in methanol $(20 \mathrm{~mL})$ was heated under reflux for $12 \mathrm{~h}$. Solvents were evaporated under reduced pressure and the residue was poured into ice/water. The precipitated material was filtered, washed with water and dried, to give $\mathbf{1}$ as a white solid (850 mg, 81\%).

4S-[(3aS,6aR)-5-Hydroxypentyl] tetrahydro-1H-thieno[3,4-d] imidazol-2(3H)-one (2) [15]. Compound 1 (500 mg, $1.93 \mathrm{mmol})$ was dissolved in $\mathrm{CH}_{2} \mathrm{Cl}_{2}(30 \mathrm{~mL})$. The mixture was cooled to $-78{ }^{\circ} \mathrm{C}$ and DIBAL (1.0 M, $6.8 \mathrm{~mL}, 6.78 \mathrm{mmol}$ ) was added; the resulting solution was stirred for $2 \mathrm{~h}$ at r.t. The mixture was then cooled to $-78{ }^{\circ} \mathrm{C}$ and quenched with $\mathrm{MeOH}$. The solvent was evaporated under reduced pressure and the residue was extracted with $\mathrm{EtOH}$ using a Soxhlet, to give 2 as a white solid (320 mg, 73\%). ${ }^{1} \mathrm{H}-\mathrm{NMR}$ (DMSO-d $)_{6}$ : $\delta=6.41$ (br. s, $1 \mathrm{H}, 3-\mathrm{NH}$ ), 6.34 (br. s, $1 \mathrm{H}, 1-\mathrm{NH}$ ), 4.35 $\left(\mathrm{t},{ }^{3} J_{5^{\prime}-\mathrm{H}}=4.9 \mathrm{~Hz}, 1 \mathrm{H}, \mathrm{OH}\right), 4.29$ (br. t, $\left.1 \mathrm{H}, 6 \mathrm{a}-\mathrm{H}\right), 4.12$ (br. t, $\left.1 \mathrm{H}, 3 \mathrm{a}-\mathrm{H}\right), 3.35$ (m, $\left.2 \mathrm{H}, 5^{\prime}-\mathrm{H}\right), 3.09$ $(\mathrm{m}, 1 \mathrm{H}, 4-\mathrm{H}), 2.81\left(\mathrm{dd},{ }^{2} J_{\mathrm{Hy}}=12.4 \mathrm{~Hz},{ }^{3} J_{6 \mathrm{a}-\mathrm{H}}=5.0 \mathrm{~Hz}, 1 \mathrm{H}, \mathrm{Hx}\right), 2.56$ (d, $\left.1 \mathrm{H}, \mathrm{Hy}\right), 1.59$ (m, $1 \mathrm{H}, 1$ '-H), $1.42\left(\mathrm{~m}, 1 \mathrm{H}, 1^{\prime}-\mathrm{H}\right), 1.40$ (m, $\left.2 \mathrm{H}, 4^{\prime}-\mathrm{H}\right), 1.30$ (m, $\left.4 \mathrm{H}, 2^{\prime}-\mathrm{H}, 33^{\prime}-\mathrm{H}\right)$ ppm; ${ }^{13} \mathrm{C}-\mathrm{NMR}$ (DMSO-d $)_{6}$ : $\delta=162.8$ (CO), 61.1 (C3a), 60.7 (C5'), 59.2 (C6a), 55.6 (C4), 39.9 (C6), 32.3 (C4'), 28.6 (C2'), 28.3 (C1'), $25.6\left(\mathrm{C}^{\prime}\right) \mathrm{ppm}$.

4S-[(3aS,6aR)-5-Iodopentyl]tetrahydro-1H-thieno[3,4-d]imidazol-2(3H)-one (3) [15]. This compound was prepared from biotin tosylate as reported [22]. The biotin tosylate $(280 \mathrm{mg}, 0.75 \mathrm{mmol})$ and $\mathrm{NaI}$ (216 $\mathrm{mg}, 0.15 \mathrm{mmol})$ were stirred in acetone $(20 \mathrm{~mL})$ for $24 \mathrm{~h}$. The solvent was removed under reduced pressure and the residue was dissolved in $\mathrm{CH}_{2} \mathrm{Cl}_{2}$ and the organic layer was successively washed with sodium thiosulfate $(1.0 \mathrm{~N})$ and water, dried over anhydrous $\mathrm{Na}_{2} \mathrm{SO}_{4}$, and concentrated under vacuum. Purification of the crude material by column chromatography on silica gel with $\mathrm{CH}_{2} \mathrm{Cl}_{2} / \mathrm{MeOH}$ (5\%) gives 3 as a white solid (335 mg, 78\%). ${ }^{1} \mathrm{H}-\mathrm{NMR}\left(\mathrm{CDCl}_{3}\right): \delta=5.07$ (br. s, $1 \mathrm{H}$, 3-NH), 4.93 (br. s, $1 \mathrm{H}, 1-\mathrm{NH}), 4.54$ (br. t, $1 \mathrm{H}, 6 \mathrm{a}-\mathrm{H}$ ), 4.34 (br. t, $1 \mathrm{H}, 3 \mathrm{a}-\mathrm{H}), 3.19$ (t, ${ }^{3} J_{4^{\prime}-\mathrm{H}}=6.9$ $\left.\mathrm{Hz}, 2 \mathrm{H}, 5^{\prime}-\mathrm{H}\right), 3.18(\mathrm{~m}, 1 \mathrm{H}, 4-\mathrm{H}), 2.94\left(\mathrm{dd},{ }^{2} J_{\mathrm{Hy}}=12.9 \mathrm{~Hz},{ }^{3} J_{6 \mathrm{a}-\mathrm{H}}=5.0 \mathrm{~Hz}, 1 \mathrm{H}, \mathrm{Hx}\right), 2.76$ (d, $\left.1 \mathrm{H}, \mathrm{Hy}\right)$, 
1.84 (m, 2 H, 4'-H), 1.69 (m, 2 H, 1'-H), 1.46 (m, 4 H, 2'-H, 3'-H) ppm; ${ }^{13} \mathrm{C}-\mathrm{NMR}\left(\mathrm{CDCl}_{3}\right): \delta=162.9$ (CO), 62.1 (C3a), 60.2 (C6a), 55.4 (C4), 40.6 (C6), 33.1 (C4'), 30.4 (C3'), 28.6 (C1'), 28.0 (C2'), 6.8 (C5') ppm.

4S-[(3aS,6aR)-5-Bromopentyl]tetrahydro-1H-thieno[3,4-d] imidazol-2(3H)-one (4) [15]. A solution of $3(800 \mathrm{mg}, 2.35 \mathrm{mmol})$ and $\mathrm{LiBr}(1.03 \mathrm{~g}, 11.76 \mathrm{mmol})$ in 2-butanone $(30 \mathrm{~mL})$ was stirred at $80{ }^{\circ} \mathrm{C}$ for $24 \mathrm{~h}$. After cooling at room temperature, $20 \mathrm{~mL}$ of $10 \% \mathrm{NaHSO}_{3}$ were added to quench the reaction. The organic layer was washed with water, dried $\left(\mathrm{MgSO}_{4}\right)$, and evaporated to dryness. The residue was purified by chromatography on silica gel with $\mathrm{CH}_{2} \mathrm{Cl}_{2} / \mathrm{MeOH}(5 \%)$ to give 4 as a white solid (595 mg, 87\%). ${ }^{1} \mathrm{H}-\mathrm{NMR}\left(\mathrm{CDCl}_{3}\right): \delta=5.65$ (br. s, $\left.1 \mathrm{H}, 3-\mathrm{NH}\right), 5.35$ (br. s, $\left.1 \mathrm{H}, 1-\mathrm{NH}\right), 4.51\left(\mathrm{dd},{ }^{3} J_{3 \mathrm{a}-\mathrm{H}}=7.8 \mathrm{~Hz}\right.$, $\left.{ }^{3} J_{\mathrm{Hx}}=4.9 \mathrm{~Hz} 1 \mathrm{H}, 6 \mathrm{a}-\mathrm{H}\right), 4.31\left(\mathrm{dd},{ }^{3} J_{4-\mathrm{H}}=4.6 \mathrm{~Hz}, 1 \mathrm{H}, 3 \mathrm{a}-\mathrm{H}\right), 3.41\left(\mathrm{t},{ }^{3} J_{4^{\prime}-\mathrm{H}}=6.7 \mathrm{~Hz}, 2 \mathrm{H}, 5^{\prime}-\mathrm{H}\right)$, $3.16\left(\mathrm{ddd}, 1 \mathrm{H},{ }^{3} J_{1^{\prime}-\mathrm{H}}=8.6 \mathrm{~Hz},{ }^{3} J_{1^{\prime}-\mathrm{H}}=6.1,4-\mathrm{H}\right), 2.92\left(\mathrm{dd},{ }^{2} J_{\mathrm{Hy}}=12.8 \mathrm{~Hz},{ }^{3} J_{6 \mathrm{a}-\mathrm{H}}=5.0 \mathrm{~Hz}, 1 \mathrm{H}, \mathrm{Hx}\right)$, 2.75 (d, $1 \mathrm{H}, \mathrm{Hy}), 1.87$ (q, $\left.{ }^{3} J_{3^{\prime}-\mathrm{H}}={ }^{3} J_{5^{\prime}-\mathrm{H}}=6.9 \mathrm{~Hz}, 2 \mathrm{H}, 4^{\prime}-\mathrm{H}\right), 1.69$ (m, $\left.2 \mathrm{H}, 1^{\prime}-\mathrm{H}\right), 1.49$ (m, $\left.2 \mathrm{H}, 3^{\prime}-\mathrm{H}\right)$, 1.45 (m, 2 H, 2'-H) ppm; ${ }^{13} \mathrm{C}-\mathrm{NMR}\left(\mathrm{CDCl}_{3}\right): \delta=163.5(\mathrm{CO}), 62.1$ (C3a), 60.1 (C6a), 55.5 (C4), 40.6 (C6), 33.8 (C5'), $32.4\left(\mathrm{C}^{\prime}\right), 28.5$ (C1'), 28.2 (C3' or $\left.\mathrm{C}^{\prime}\right), 28.1$ (C2' or $\left.\mathrm{C} 1^{\prime}\right)$ ppm.

4S-[(3aS,6aR)-Hept-6-ynyl-tetrahydro-1H-thieno[3,4-d]imidazol-2(3H)-one (5) [15]. Lithium acetylide-ethylendiamine complex (194 mg, $2.1 \mathrm{mmol})$ was suspended in DMSO (5 mL) and cooled to $15{ }^{\circ} \mathrm{C}$. A solution of $4(200 \mathrm{mg}, 0.68 \mathrm{mmol})$ in DMSO $(3 \mathrm{~mL})$ was added and the mixture was stirred for $1.5 \mathrm{~h}$. The reaction mixture was poured over an ice/brine and the crude material extracted with $\mathrm{CH}_{2} \mathrm{Cl}_{2}$. The organic layer was washed with water, dried $\left(\mathrm{MgSO}_{4}\right)$, and evaporated to dryness. The residue was purified by chromatography on silica gel with $\mathrm{CH}_{2} \mathrm{Cl}_{2} / \mathrm{MeOH}(5 \%)$ to give 5 as a white solid (146 mg, 90\%). ${ }^{1} \mathrm{H}-\mathrm{NMR}\left(\mathrm{CDCl}_{3}\right): \delta=5.02$ (br. s, $\left.1 \mathrm{H}, 3-\mathrm{NH}\right), 4.95$ (br. s, $\left.1 \mathrm{H}, 1-\mathrm{NH}\right), 4.51$ $\left(\mathrm{dddd},{ }^{3} J_{3 \mathrm{a}-\mathrm{H}}=7.8 \mathrm{~Hz},{ }^{3} J_{\mathrm{Hx}}=5.1 \mathrm{~Hz},{ }^{3} J_{1-\mathrm{NH}}={ }^{3} J_{\mathrm{Hy}}=1.2 \mathrm{~Hz}, 1 \mathrm{H}, 6 \mathrm{a}-\mathrm{H}\right), 4.31\left(\mathrm{ddd},{ }^{3} J_{4-\mathrm{H}}=4.7 \mathrm{~Hz}\right.$, $\left.{ }^{3} J_{3-\mathrm{NH}}=1.5,1 \mathrm{H}, 3 \mathrm{a}-\mathrm{H}\right), 3.17\left(\mathrm{ddd}, 1 \mathrm{H},{ }^{3} J_{1^{\prime}-\mathrm{H}}=8.5 \mathrm{~Hz},{ }^{3} J_{1^{\prime}-\mathrm{H}}=6.5 \mathrm{~Hz}, 4-\mathrm{H}\right), 2.93\left(\mathrm{dd},{ }^{2} J_{\mathrm{Hy}}=12.8 \mathrm{~Hz}\right.$, $\left.{ }^{3} J_{6 \mathrm{a}-\mathrm{H}}=5.1 \mathrm{~Hz}, 1 \mathrm{H}, \mathrm{Hx}\right), 2.74(\mathrm{~d}, 1 \mathrm{H}, \mathrm{Hy}), 2.19\left(\mathrm{td},{ }^{3} J_{4^{\prime}-\mathrm{H}}=6.8 \mathrm{~Hz},{ }^{4} J_{7^{\prime}-\mathrm{H}}=2.7 \mathrm{~Hz}, 2 \mathrm{H}, 5^{\prime}-\mathrm{H}\right), 1.94$ (t, $\left.1 \mathrm{H}, 7^{\prime}-\mathrm{H}\right), 1.68$ (m, 2 H, 1'-H), 1.54 (m, 2 H, 4'-H), 1.45 (m, 4 H, 2'-H, 3'-H) ppm; ${ }^{13} \mathrm{C}-\mathrm{NMR}$ $\left(\mathrm{CDCl}_{3}\right): \delta=162.9(\mathrm{CO}), 84.4$ (C6’), 68.4 (C7'), 62.0 (C3a), 60.1 (C6a), 55.4 (C4), 40.5 (C6), 28.6 (C2'/C3'), 28.5 (C1'), 28.1 (C4'), 18.3 (C5') ppm.

\subsection{NMR titrations}

Association constants were calculated through ${ }^{1} \mathrm{H}-\mathrm{NMR}$ titration experiments in $\mathrm{CDCl}_{3}$ (and in some cases by adding a $10 \% \mathrm{MeOD}$ to the $\mathrm{CDCl}_{3}$ ) using the EQNMR software to analyze the results [19]. Changes in the chemical shifts of the N-H groups of receptors were used. With respect to the non Saturation Titration conditions $(n S T)$ we proceeded as described already by ourselves [6-9]. To perform the measurement of $K_{\mathrm{b}}$, the host and guest solutions were prepared in a volumetric flask of the appropriate volume $(2 \mathrm{~mL}$ to $5 \mathrm{~mL}) .0 .5 \mathrm{~mL}$ of the host solution I-III was taken, put in a NMR tube and successive additions of solutions of guests 1-5 aliquots were made. The number of additions was continued until saturation titration conditions (ST) or until reached the 0.8 value of saturation (nST). We present here a typical example of the experimental data for ST and nST conditions (Table 3 and Table 4). 
Table 3. Representative table for a Saturation Titration conditions (ST) of host I with (+)biotin methyl ester 1 . Initial [host] $=8.40 \times 10^{-3}$, initial [guest] $=7.78 \times 10^{-2}$.

\begin{tabular}{lccccc}
\hline $\begin{array}{c}\text { Volume of added guest }(\mathbf{I}) \\
(\boldsymbol{\mu} \mathbf{L})\end{array}$ & $\begin{array}{c}\text { Total-Volume } \\
(\boldsymbol{\mu} \mathbf{L})\end{array}$ & $\begin{array}{c}\text { [host I] } \\
\left(\mathbf{1 0}^{-3} \mathbf{M}\right)\end{array}$ & $\begin{array}{c}\text { [guest 1] } \\
\left(\mathbf{1 0}^{-3} \mathbf{M}\right)\end{array}$ & $\begin{array}{c}\text { Equivalents of } \\
\text { added guest }\end{array}$ & $\begin{array}{c}\boldsymbol{\delta}(\mathbf{N H}) \\
(\mathbf{p p m})\end{array}$ \\
\hline 0 & 500 & 8.40 & 0 & 0 & 10.7474 \\
5 & 505 & 8.32 & 0.77 & 0.09268 & 10.8176 \\
10 & 510 & 8.24 & 1.53 & 0.18537 & 10.8729 \\
20 & 520 & 8.08 & 3.00 & 0.37074 & 10.9920 \\
30 & 530 & 7.93 & 4.41 & 0.55611 & 11.0745 \\
40 & 540 & 7.78 & 5.77 & 0.74147 & 11.1484 \\
65 & 565 & 7.44 & 8.96 & 1.20489 & 11.2488 \\
90 & 590 & 7.12 & 11.88 & 1.66832 & 11.2949 \\
115 & 615 & 6.83 & 14.56 & 2.13174 & 11.3352 \\
215 & 715 & 5.88 & 23.42 & 3.98542 & 11.4600 \\
315 & 815 & 5.15 & 30.10 & 5.83910 & 11.5452 \\
565 & 1,065 & 3.94 & 41.31 & 10.47332 & 11.6432 \\
815 & 1,315 & 3.19 & 48.27 & 15.10753 & 11.6570 \\
915 & 1,415 & 2.97 & 50.36 & 16.96121 & 11.6582 \\
\hline
\end{tabular}

Table 4. Representative table for a non Saturation Titration conditions (nST) of host I with (+)-biotin methyl ester 1. Initial [host] $=4.31 \times 10^{-4}$, initial [guest] $=9.24 \times 10^{-4}$.

\begin{tabular}{cccccc}
\hline $\begin{array}{c}\text { Volume of added guest }(\mathbf{I}) \\
(\boldsymbol{\mu} \mathbf{L})\end{array}$ & $\begin{array}{c}\text { Total- } \\
\text { Volume }(\boldsymbol{\mu L})\end{array}$ & $\begin{array}{c}\text { [host I] } \\
\left(\mathbf{1 0}^{-4} \mathbf{M}\right)\end{array}$ & $\begin{array}{c}\text { [guest 1] } \\
\left(\mathbf{1 0}^{-4} \mathbf{M}\right)\end{array}$ & $\begin{array}{c}\text { Equivalents of } \\
\text { added guest }\end{array}$ & $\begin{array}{c}\boldsymbol{\delta} \mathbf{( N H )} \\
(\mathbf{p p m})\end{array}$ \\
\hline 20 & 520 & 4.14 & 0.355 & 0.08588 & 10.8521 \\
30 & 530 & 4.07 & 0.523 & 0.12882 & 11.0125 \\
40 & 540 & 3.99 & 0.686 & 0.17176 & 11.1025 \\
65 & 565 & 3.81 & 1.060 & 0.27911 & 11.1730 \\
90 & 590 & 3.65 & 1.410 & 0.38646 & 11.2587 \\
115 & 615 & 3.50 & 1.730 & 0.49380 & 11.2925 \\
215 & 715 & 3.01 & 2.780 & 0.92320 & 11.3014 \\
315 & 815 & 2.64 & 3.580 & 1.35259 & 11.3514 \\
\hline
\end{tabular}

\section{Conclusions}

The naphthyridine receptors II and III exhibit a high selectivity towards the (+)-biotin methyl ester (1), due to the stabilization of the complex by additional hydrogen bonds, with an association constant $K_{b}=6.7 \times 10^{4}$ and $2.5 \times 10^{5} \mathrm{M}^{-1}$, respectively, in $\mathrm{CDCl}_{3}$. These studies illustrate the capability to modulate the association constant of receptors depending on the biotin type analogue. We have found that the selectivity follows the sequence: $\mathrm{CO}_{2} \mathrm{Me}>>\mathrm{Br} \geq \mathrm{I} \geq$ acetylide.

The simple quantitative model (Table 2) allows to go a step further. The hosts classify in the order: III (our host) [8] > II (Goswami host) [13] > I (Thummel host) [12]. Concerning the guests, the order is $\mathbf{G} 2 \geq \mathbf{G 1}((+)$-biotin methyl ester $)>>\mathrm{Br} \approx \mathrm{I} \approx$ acetylide. Although $\mathbf{G} 2$ is insoluble in chloroform, it has an affinity for host III slightly better than G1. Possibly the terminal OH anchors to the host. This make G2 a promising candidate for further studies, for instance, modifying the polymethylene chain length. 


\section{Acknowledgements}

This work has been financed by the Spanish MEC (CTQ2007-62113).

\section{References and Notes}

1. Kumar, S.; Singh, H.; Sharma, R. Role of amide and urea moieties in molecular recognition. $J$. Indian Chem. Soc. 2003, 80, 1111-1128.

2. Bell, T.W.; Hext, N.M. Supramolecular optical chemosensors for organic analytes. Chem. Soc. Rev. 2004, 33, 589-598.

3. Gale, P.A.; Quesada, R. Anion coordination and anion-templated assembly: highlights from 2002 to 2004. Coord. Chem. Rev. 2006, 250, 3219-3244.

4. Kang, S.O.; Begum, R.A.; Bowman-James, K. Amide-based ligands for anion coordination. Angew. Chem. Int. Ed. 2006, 45, 7882-7894.

5. Steed, J.W.; Turner, D.R.; Wallace, K.J. The host component is defined as an organic molecule or ion whose binding sites converge in the complex. The guest component is any molecule or ion whose binding sites diverge in the complex. In Core Concepts in Supramolecular Chemistry and Nanochemistry; John Wiley \& Sons: Chichester, UK, 2007; p. 2.

6. Claramunt, R.M.; Herranz, F.; Santa María, M.D.; Jaime, C.; de Federico, M.; Elguero, J. Towards the design of host-guest complexes: biotin and urea derivatives versus artificial receptors. Biosens. Bioelectron. 2004, 20, 1242-1249.

7. Claramunt, R.M.; Herranz, F.; Santa María, M.D.; Pinilla, E.; Torres, M.R.; Elguero, J. Molecular recognition of biotin, barbital and tolbutamide with new synthetic receptors. Tetrahedron 2005, 61, 5089-5100.

8. Herranz, F.; Santa María, M.D.; Claramunt, R.M. Molecular recognition: improved binding of biotin derivatives with synthetic receptors. J. Org. Chem. 2006, 71, 2944-2951.

9. Herranz, F.; Santa María, M.D.; Claramunt, R.M. Host-guest chemistry of tolbutamide. Molecules 2006, 11, 478-485.

10. Herranz, F.; Santa María, M.D.; Claramunt, R.M. A new tool for the rational design of methylbiotin hosts. Tetrahedron Lett. 2006, 47, 9017-9020.

11. Santa María, D.; Claramunt, R.M.; Herranz, F.; Alkorta, I.; Elguero, J. A theoretical and experimental NMR study of (+)-biotin methyl ester. J. Mol. Struct. 2009, 920, 323-326.

12. Hedge, V.; Hung, C.-Y.; Madhukar, P.; Cunningham, R.; Höpfner, T.; Thummel, R.P. Design of receptors for urea derivatives based on the pyrido[3,2-g]indole subunit. J. Am. Chem. Soc. 1993, 115, 872-878.

13. Goswami, S.; Mukherjee, R. Molecular recognition: a simple dinaphthyridine receptor for urea. Tetrahedron Lett. 1997, 38, 1619-1622.

14. Dixon, R.W.; Radmer, R.J.; Kuhn, B.; Kollman, P.A. Theoretical and experimental studies of biotin analogues that bind almost as tightly to streptavidin as biotin. J. Org. Chem. 2002, 67, 1827-1837.

15. Corona, C.; Bryant, B.K.; Arterburn, J.B. Synthesis of a biotin-derived alkyne for Pd-catalyzed coupling reactions. Org. Lett. 2006, 8, 1883-1886. 
16. Job, P. Studies on the formation of complex minerals in solution and on their stability. Ann. Chim. 1928, 9, 113-203.

17. Connors, K.A. Binding Constants: The Measurement of Molecular Complex Stability. WileyInterscience: New York, NY, USA, 1987.

18. Schneider, H.-J.; Yatsimirsky, A.K. Principles and methods in supramolecular chemistry. John Wiley \& Sons: The Atrium, Southern Gate, Chichester, West Sussex, UK, 2000.

19. Hynes, M.J. EQNMR: a computer program for the calculation of stability constants from nuclear magnetic resonance chemical shift data. J. Chem. Soc., Dalton Trans. 1993, 311-312.

20. Kubinyi, H. Free Wilson analysis. Theory, applications and its relationship to Hansch analysis. QSAR 1988, 7, 121-133.

21. Alkorta, I.; Blanco, F.; Elguero, J. Application of Free-Wilson matrices to the analysis of the tautomerism and aromaticity DFT study. Tetrahedron 2008, 19, 3826-3836.

22. DeLaLuz, P.J.; Golinski, M.; Watt, D.S.; Vanaman, T.C. Synthesis and use of a biotinylated 3azidophenothiazine to photolabel both amino- and carboxyl-terminal sites in calmodulin. Bioconjugate Chem. 1995, 6, 558.

Sample Availability: Samples of the compounds, hosts I, II, III and guests 1-5 are available from authors.

(C) 2010 by the authors; licensee Molecular Diversity Preservation International, Basel, Switzerland. This article is an open-access article distributed under the terms and conditions of the Creative Commons Attribution license (http://creativecommons.org/licenses/by/3.0/). 